\title{
Breastfeeding Pattern and Early Childhood Caries
}

\author{
Susi Susi ${ }^{1}$, Murniwati ${ }^{2}$, Febrina Rahmadani ${ }^{3}$ \\ \{susi@dent.unand.ac.id\} \\ Dental Public Health Departement, Faculty of Dentistry Universitas Andalas, Padang Indonesia ${ }^{1,2,3}$
}

\begin{abstract}
The 2016 Global Burden of Disease Study estimates that 486 million children worldwide suffer from Early Childhood Caries (ECC), and the World Health Organization estimates that $60-90 \%$ of children suffer from caries. Early Childhood Caries (ECC) is a term used for caries that occurs in primary teeth in children under 71 month of age. Some researchers stated that ECC is related to the breastfeeding pattern. This study aims to look at the relationship between breastfeeding patterns with Early Childhood Caries in children aged 2-3 years in the city of Padang. A cross-sectional study in Integrated Service Post located in Koto Tangah and East Padang Subdistrict, Padang City, Indonesia, was conducted. Purposive sampling was selected 70 pairs of mother-children (aged 2-3 years). A questionnaire performed to observe the feeding pattern, and the odontogram was used to ECC determined. Four students of Faculty of Dentistry, which has been calibrated, were collected data. Data were analyzed statistically using Chi-Square test $(\mathrm{p}<0.05)$. The result showed that prevalence ECC $80 \%$ (95\% CI 70\%-90\%) with a mean of deft $3.04 \pm 2.24$ (95\% CI 2.51- 3.58). Children who got breastfeeding and complementary food until the age of 24 months have the highest deft index (3.23), while children who are breastfed and bottle-fed up to 6 months have the lowest deft index (2.56). There was no significant relationship between breastfeeding patterns and Early Childhood Caries of children 2-3 years old in Padang.
\end{abstract}

Keywords: ECC, deft, breastfeeding, prevalence, complimentary food

\section{Introduction}

Caries is a major problem in dental health, affecting 2.43 billion people $(35.3 \%)$ of the world's population [1]. Caries is a non-infectious disease that begins to occur when the tooth starts to erupt. Early Childhood Caries (ECC) is caries affecting the deciduous teeth of children under 71 months [2]. The prevalence of ECC in the world is between $6 \%-90 \%$, and the highest prevalence is in developing countries [3]. The prevalence of ECC in Bukittinggi, Indonesia, was $51.8 \%$ in children aged two to three years [4].

The World Health Organization and Federation Dentaire Internationale (FDI) sets global goals for oral health in 2020 and demand each country to improve their dental health status [5]. Nowadays, the basic data of caries risk factors that can be modified to reduce the incidence of caries in developing countries still lacking, including Indonesia. Research on ECC has not been done much in Indonesia. Many risk factors that caused caries such as milkdrinking patterns, eating patterns, and economic status [5,6]. American Academiy of Pediatric Dentistry made dietary guidelines to reduce caries rates[2]. The model is providing food to children, including milk consumption, which is an essential factor causing ECC [7]. This 
study aims to determine the prevalence of ECC and evaluate the relationship between breastfeeding and ECC in children aged two to three years in Padang.

\section{Method}

A crossectional study approach conducted in February-May 2017 in integrated post service (Posyandu) of Padang Timur dan Koto Tangah district, Padang, Indonesia. Permission for the research obtained from Research Ethics no. 065/KEP/FK/2017 Faculty of Medicine, Andalas University, Padang West Sumatera. The Sample size calculated using a crosssectional difference test of two proportions with a formula based on $95 \%$ confidence level, p1 $=0.642$, and $\mathrm{p} 2=0.224$. The sample consists of 70 pairs of mothers with children aged two to three years. Based on the selected cluster sampling, 2 Posyandu in the downtown area (Padang Timur) and 3 Posyandu in the suburbs (Koto Tangah) were selected.

The data was taken by a dentist and four students, the Andalas University Dentistry. They had been calibrated before with intra-examiners and inter-examiners with conformity values of 0.8 . The pattern of breastfeeding used questions and an odontogram sheet to assess the ECC. During a dental examination, the sample sit with adequate lighting accompanied by parents. ECC examination has done visually, and the mouth mirror can used if needed.

The breastfeeding pattern categorized into 0 -six months and six months- 24 months group. Data analyzed by Chi-square with a value of $\mathrm{p}<0.05$ to assess the relationship between breastfeeding patterns and ECC.

\section{Result}

ECC prevalence was $80 \%(95 \%$ CI $70 \%-90 \%)$ with mean deft index of $3.04 \pm 2.24(95 \% \mathrm{CI}$ 2.51-3.58). Table 1. shows an overview of sample characteristics based on gender, age, and residential area.

Tabel 1. Sample characteristic and deft index

\begin{tabular}{lllll}
\hline Variable & \multicolumn{2}{c}{ Prevalence ECC } & deft index & SD \\
\hline Gender & 35 & $28(80.0 \%)$ & 3.09 & \\
female & 35 & $28(80.0 \%)$ & 3.00 & 2.188 \\
Male & & & & 2.352 \\
\hline Age & 30 & $25(83.3 \%)$ & 3.47 & 2207 \\
three years old & 40 & $31(77.5 \%)$ & 2.73 & 2.255 \\
two years old & & & & \\
\hline Location & 21 & $20(95.2 \%)$ & 4.00 & 2.490 \\
Downtown & 49 & $36(73.7 \%)$ & 2.63 & 2.018 \\
Suburb & &
\end{tabular}

In table 2., the highest average of the deft index is 3.23 in children who breastfed and eat complementary foods, while the lowest deft index is in children who have breastfed, bottlefed, and complementary foods. The highest prevalence of ECC was in breastfeeding, bottle feeding, and complimentary food group. 
Table 2. Breastfeeding and deft index

\begin{tabular}{lllll}
\hline \multicolumn{1}{c}{ Variable } & n & $\begin{array}{c}\text { Prevalence } \\
\text { ECC (\%) }\end{array}$ & Index deft & SD \\
\hline 0-6 month & 18 & 72.2 & 2.56 & 1.917 \\
Breastfeeding, bottle-feeding & 52 & 82.7 & 3.21 & 2.388 \\
Breastfeeding & 48 & 83.3 & 2.96 & 2.133 \\
\hline six months -24 month & & & 3.23 & 2.544 \\
Breastfeeding, bottle feeding, and & 22 & 72.7 & & \\
Complimentary food & & & & \\
Breastfeeding and Complimentary food & &
\end{tabular}

Table 3. Breastfeeding Pattern and Early Childhood Caries

\begin{tabular}{|c|c|c|c|c|c|c|c|c|c|c|}
\hline \multirow{3}{*}{ Variables } & \multicolumn{6}{|c|}{ Early Childhood Caries } & \multirow{3}{*}{$\begin{array}{c}\text { p- } \\
\text { value }\end{array}$} & \multirow{3}{*}{ OR } & \multicolumn{2}{|c|}{$95 \% \mathrm{CI}$} \\
\hline & \multicolumn{2}{|c|}{ Yes } & \multicolumn{2}{|c|}{ No } & \multicolumn{2}{|c|}{ Total } & & & & \\
\hline & $\mathrm{n}$ & $\%$ & $\mathbf{n}$ & $\%$ & $\mathbf{n}$ & $\%$ & & & lower & upper \\
\hline \multicolumn{11}{|l|}{$0 \geq 6$ month } \\
\hline $\begin{array}{l}\text { Bottle and } \\
\text { breastfeeding }\end{array}$ & 13 & 72.2 & 5 & 27.8 & 18 & 100.0 & \multirow{2}{*}{0.236} & \multirow{2}{*}{0.544} & \multirow{2}{*}{0.155} & \multirow{2}{*}{1.913} \\
\hline Breastfeeding & 43 & 82.7 & 9 & 17.3 & 52 & 100.0 & & & & \\
\hline \multicolumn{11}{|l|}{ six months $\geq 24$ month } \\
\hline \multirow{2}{*}{$\begin{array}{l}\text { Breastfeeding, bottle } \\
\text { feeding, and } \\
\text { Complimentary food } \\
\text { Breastfeeding and } \\
\text { Complimentary food }\end{array}$} & 40 & 83,3 & 8 & 16.7 & 48 & 100.0 & \multirow[t]{2}{*}{0.236} & \multirow[t]{2}{*}{1.875} & \multirow[t]{2}{*}{0.561} & \multirow[t]{2}{*}{6.268} \\
\hline & 16 & 72.7 & 6 & 27.3 & 22 & 100.0 & & & & \\
\hline
\end{tabular}

The results showed the prevalence of ECC was $80 \%(95 \%$ CI $70 \%-90 \%)$ in children aged two to three years old in Padang. This result is higher than the prevalence of ECC for children aged 12-38 months in Jakarta $(52.7 \%)$ and Bukittinggi $(51,8 \%)$ [4, 8]. The ECC prevalence in this study is very far from the WHO target were children under 12 years have to be in caries-free in 2020 and also the Indonesian Government's goal that children under 12 years should be caries-free in 2030 [5, 9].

The mean of the deft index in this study was $3.04 \pm 2.24$ (95\% CI 2.51- 3.58). The average sample had three or more caries in the deciduous teeth. Caries begin to occur when a tooth erupts, and a thin enamel structure facilitates the development of caries in primary teeth. According to WHO, the deft index of 3.04 included in the moderate category. The deft index in this study is higher than the results of research for children aged two to three years in Bukittinggi, which is 2.33 [4].

Based on the gender, there was no difference in the prevalence of ECC, whereas based on age, there was an increase in prevalence from the age of two years to three years $(77.5 \%$ $83.3 \%$ ). Age is a risk factor for caries because increasing age causes more prolonged exposure to teeth. Based on residence, the respondents who live in the City Center had a higher caries prevalence. It can be due to cariogenic snacks that are easier to get to the city center.

The children who have breastfed until the age of 6 months in this study were 52 children in total (74.28\%). In this research, breastfed can not categorize as exclusive breastfeeding. Exclusive breastfeeding cannot carried out according to guidelines, and most respondents give 
water to their children after give breastfed. The results showed that the highest prevalence of ECC (82.7\%) and deft index (3.21) was in the group who have breastfed from age 0-6 months. At the age of 6 months, primary teeth erupt, and the caries process begins.

Based on breastfeeding patterns of children aged six months-24 months, the highest prevalence of ECC was in the group that has breastfed and complementary foods. The wrong breastfeeding pattern can increase the occurrence of caries. AAPDC provides guidance when a tooth erupts, and breastfeeding should be reduced or stopped at night. The child's teeth should clean from the milk that left in the mouth when the child falls asleep[2]. The remaining liquid in the mouth can contact with the surface of the teeth. While the child is sleeping, there is a decrease in swallowing activity and salivary flow so that fluid pooled in the oral cavity [10] .

Based on the results of the chi-square statistical test, the p-value of 0.236 obtained, which means that there was no significant relationship between breastfeeding and ECC. The OR value is 0.544 , which means that children who have breastfeeding and bottle feeding has a 0.544 times more chance to ECC compared to those who have breastfeeding until the age of six months. The OR value is 1.875 , which means that children who have breastfeeding, bottle feeding, and complimentary food have 1.875 times chance to ECC compared who have breastfeeding and complimentary food.

The results of this study are in line with Setiawati's research, which states that there is no significant relationship between breastfeeding and the severity of ECC. The results of this study are different from other researchers $[11,12]$.

Caries was caused by multifactorial such as etiological factors and predisposing factors. The etiological factor is the main factor of caries that include host, microorganisms, substrate, and time. Predisposing factors consist of the environment, socioeconomic conditions and behavior, characteristics, and eating patterns. Many other factors can be caries and can be different in each person.

\section{Conclusion}

The prevalence and deft index of ECC in this study considered high, so efforts are needed to improve children's oral health. Promotive and preventive efforts to modify ECC risk factors should do. There is no significant relationship between breastfeeding patterns and ECC.

\section{References}

[1] Vos T, Flaxman AD, Naghavi M, Lozano R, Michaud C, ezzati M, et al. Years lived with disability (YLDs) for 1160 sequelae of 289 diseases and injuries 1990-2010; a systematic analysis for the Global Burden of Disease study 2010. Lancet. 380(9859); pp.2163-96. (2012)

[2] American Academy of Pediatric Dentistry. Policy on early childhood caries (ECC) classification, consequences, and preventive strategies. Pediatr Dent; 37: pp. 50-52.( 2014)

[3] O' Mullane D, Parnell C; Early Childhood Caries: a complex problem requiring a complex solution. Community Dent Health, pp. 28:254 (2011)

[4] Susi Susi, Murniwati M, Kasuma N, Minarni M. Analysis of breastfeeding pattern with early childhood caries. World J Dent; 9(3): pp.197-200. (2018)

[5] FDI: Global Goals for Oral Health 2020; International Dental Journal, 53, pp. 285-288 (2003) 
[6] Rahul Naidu, June Nunn, Alan Kelly; socio-behavioural factors and early childhood caries; a cross-sectional study of preschool children in central Trinidad. BMC oral Health, pp.13.30 (2013)

[7] Rebecca Harris, Alison D Nicoll, Pauline M Adair, Cynthia M Pine: Risk factor for dental caries in young children ; a systematic review of the literature. Community Dental Health. 21 (supplement), pp 71-85 (2004)

[8] Setiawati F, Djoharnas H, Darwita RR. Breastfeeding and early Childhood Caries (ECC) Severity of Children under three years old in DKI Jakarta. Makara Journal of Research. 12(2) pp.86-91 (2008)

[9] Kementrian Kesehatan Republik Indonesia. Pedoman Riset Kesehatan Dasar (2017).

[10] Erikkson 1, Lif Holgerson p, Johansson I, Saliva and Tooth Biofilm Bacterial microbiota in Adolescents in A Low caries community. Sci Rep: 7(1) pp5861 (2017)

[11] Yazeed Abdullah Alhabdan, Abdulhameed Ghassan Albesr, Nagarajkumar Yenugadhati, Hoda Jradi: Prevakence of dental caries associated factors among primary school children: a populationbased cross-sectional study in Riyadh, Saudi Arabia; Environmental Health and Preventive Mecine (2018) 23-60

[12] Jibieke Wulaerhan, Ayinuer Abudureyimu, Xue-Li Bao, Jin Zhao; Risk determinants associated with early childhood caries in Ughur children: a preschool-based cross-sectional study; BMC Oral Health, 2014, 14:136 